\title{
Integrated water management concept for craft villages - example from the food processing craft village Dai Lam
}

\author{
Đề án quản lý nước tích hợp cho làng nghề - Thí dụ tù̀ làng nghề chế biến thực \\ phẩm Đại Lâm \\ Short communication
}

Hahn, Celia ${ }^{1}$; Meier, Sebastian ${ }^{2}$; Weichgrebe, Dirk ${ }^{2}$; Tran, Thi Nguyet ${ }^{1}$; Appel, Holger ${ }^{3}$; Fechter, Leonhard ${ }^{4}$; Werner, Peter ${ }^{1}$

${ }^{1}$ Institute of Waste Management and Contaminated Site Treatment, Technische Universität Dresden, Pratzschwitzer Str. 15, 01796 Pirna, Germany; ${ }^{2}$ Institute of Water Quality and Waste Management, Leibniz Universität Hannover, Welfengarten 1, 30167 Hannover, Germany; ${ }^{3}$ VIS International Ltd., Goerzallee 305 A, 14167 Berlin, Germany; ${ }^{4} H e r b s t ~ U m-$ welttechnik Ltd., Goerzallee 305 A, 14167 Berlin, Germany

\begin{abstract}
Craft villages played a significant role in the development of Vietnam's rural economy for a long time. The range of products and production methods, including the processing of materials and chemicals, are now adapted to modern market requirements but environmental and labour protection issues are not adequately considered in the management of the craft villages. The reasons are various: poor education of responsible operators, deficient technical equipment or missing regulatory framework and implementation of existing regulations. The INHAND project (Integrated Water Management Concept for Craft Villages) started in 2011 and is studying the food processing village of Dai Lam located on the banks of the Cau River in the Bac Ninh province (about $40 \mathrm{~km}$ NE of the capital Hanoi). The household-scale business focus mainly on rice and cassava processing with 200 out of 1000 households producing alcohol from cassava and rice, 10 households producing tofu, and 30 households recycling aluminium. In addition, most households also raise pigs. The wastewater is released mostly untreated into the receiving stream. Within the framework of the INHAND project, four German und two Vietnamese partners will conduct a basic analysis inventory in the village with identification of suitable measure for an integrated, environmentally sound concept for the removal and reuse of all output streams. The second major task of the 3.5 years research project is the conceptualisation, development and implementation of pilot-scale treatment facilities in the village and the scientific monitoring of their planning and operation.
\end{abstract}

Đã tù lâu, làng nghề đóng vai trò quan trọng trong quá trình phát triển kinh tế nông nghiệp tại Việt Nam. Các sản phẩm và phuơng thức sản xuất, bao gồm cả giai đoạn xủ lý vật liệu và hóa chất, đã từng buớc được cái tiến cho phù hợp với yêu cầu của thị truờng hiện đại. Tuy nhiên, nhũ̃ng yếu tố về môi truờng và an toàn lao động vẫn chưa được quan tâm đúng múc tại các làng nghề do nhiều nguyên nhân nhu: trình độ của nhà sản xuất, vận hành còn hạn hẹp, thiếu trang thiết bị kỹ thuật, các quy chuẩn còn thiếu hoặc chua được thi hành triệt để. Dự án INHAND (đề án xử lý nuoớc tổng thể cho làng nghề) được khởi động tù năm 2011 và hiện đang tiến hành nghiên cứu làng nghề chế biến thực phẩm Đại Lâm, nằm bên bò̀ song Cầu, thuộc tỉnh Bắc Ninh, cách Hà Nội $40 \mathrm{~km}$. Mô hình kinh tế hộ gia đình tại làng chủ yếu tập trung vào chế biến gạo và sắn: 200 trong số 1000 hộ gia đình nấu ruợu gạo và sắn, 10 hộ sản xuát đậu phu, 30 hộ tái chế nhôm. Ngoài ra, gần nhu tất cả các hộ đều có nuôi lợn. Nước thải của làng được dẫn trực tiếp ra các khối nước mở, gần nhu không qua xủ lý. Trong khuôn khổ dụ án INHAND, bốn đối tác Đức và hai đối tác Việt Nam sẽ tiến hành phân tích hiện trạng môi truờng của làng để tìm ra nhũng biện pháp thich hợ nhằm xủ lý và tái sủ dụng các dòng thải. Nhiệm vu thú hai trong thời gian 3,5 năm của dư án là lập ra đề án, phát triển và triển khai các trạ xử lý ở quy mô thử nghiẹm, đồng thời quan trắc khoa học các quá trình thiết kế và vận hành.

Keywords: integrated water management, craft villages, Dai Lam, Bac Ninh, wastewater 


\section{Introduction}

Vietnam's economy has passed an emerging development for the last 20 years and this had led to an evident participation in the global economic system. The increasing industrialisation yields a continuously growing number of industrial parks, but a great part of the production of goods of any branch takes place in so called 'craft villages'. These villages originally produced traditional goods like ceramics or textiles in seasons with less work in the rice fields. Nowadays the villages adapted to the modern production requirements and changed to downright small industrial zones, producing almost any kind of goods.

The environmental and labour protection plays an exiguous role in the management of the villages. The reasons are various: poor education of the responsible operating persons, deficient technical equipment or missing regulatory framework. In the frame of a fact finding mission of the German Federal Ministries for Education and Research (BMBF) and for Economic Cooperation and Development (BMZ) with Vietnamese authorities, the Bac Ninh province was identified as model region for a study to ameliorate the environmental situation in craft villages focussing on food processing industries.

High organic contaminations in wastewater lead - if no treatment facility is connected upstream - to over fertilisation of the surrounding water bodies and to a big, possibly not reversible change of their ecosystem. Moreover, this yields to a vast modification in subsoil redox conditions, which causes the mobilisation of the geogenic Arsenic (reduction of As V to toxic As III).

\section{The approach}

The object of investigation is Dai Lam village, a rice and manioc-processing village, which is also running some piggeries. The village is situated on the banks of the Cau River in the province of Bac Ninh, about $40 \mathrm{~km}$ northeast of the capital Hanoi (Figure 1).

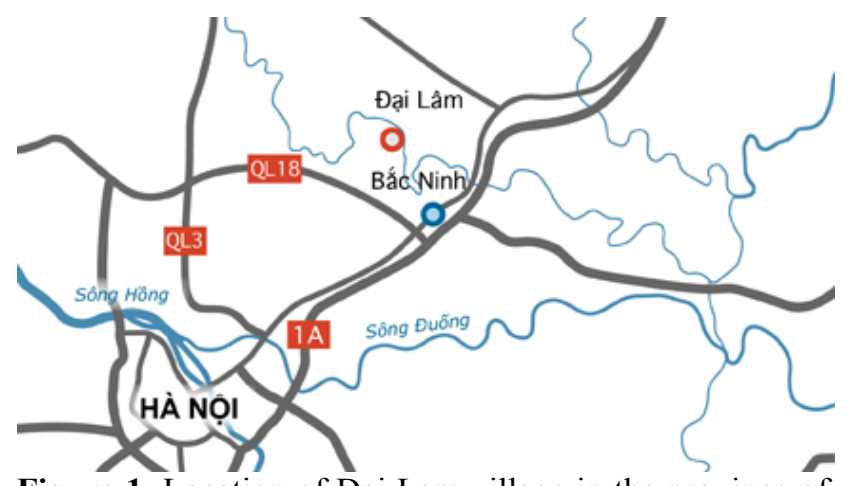

Figure 1. Location of Dai Lam village in the province of Bac Ninh

In the first phase of the project the partners will summarize all available socio-economic data and will collect chemical, physical and biological data from the main output streams, as well as information on production processes. This phase, the basic inventory, will be the fundament for the adjacent work packages.
After evaluation of the basic data, one of the main tasks of the project is to develop an integrated water managing system. Currently all wastewater streams which contain a high and seasonal varying quantity of organic material are collected by an existing canal system in one open canal which leads to the canal system of the surrounding rice fields. The high organic content, resulting from the rice and manioc processing as well as from the piggeries, households and from one restaurant shall be treated together anaerobic in order to realize a carbon neutral transformation to biogas. The digestate will be dried and thus available as fertilizer.

A multi-step pilot treatment plant will be designed, constructed and tested on site. The plant will consist of: 1) anaerobic treatment facility, 2) aerobic water treatment facility for the organic matter and 3) low energy facility for digestate treatment. Each part will follow the current state of the art, but the components need to be adapted to the local preconditions. The future operating institution will be involved from the first step like data collection to the final operation of all technical equipment. All output streams will be analysed regarding a holistically consideration of the concept (for example, iron hydroxide from the waterworks can be used in a feasible manner for desulphurisation of the biogas).

The production in the villages is lasting several decades and thus it is likely, that waste material has had been dumped in the proximity of the village. These sites are potentially threatening the groundwater and should be investigated and assessed. The project aims to develop a databank for the craft villages in Bac Ninh as basis for implementation of additional projects.

\section{Tasks}

\subsection{Basic analyses inventory}

- An extensive analysis of the current situation in the village and inventory (socio-economic, production process with regard to collection and disposal of waste and wastewater and the current environmental situation);

- Identification and analysis of possible pre-measures and possesses in support of an environmental sound treatment of wastewater and residuals (reduction of contaminants, recycling, choice of means of production);

- Concept for integrated materials flow management considering any production wastewater stream and residuals, as well as household wastewater;

- Assessment of possible contaminated sites;

- Development of an integrated, environmentally sound concept for the use and removal of all output streams (wastewater, sludge, waste, energy) for the craft villages in the conflict field of traditions and industrialisation. 


\subsection{Development and implementation of test facilities}

- Measures for implementation of the concept and test facilities;

- Conception, construction and operation of the treatment facilities. The technologies for the treatment of the highly organic loaded wastewater comprise a part of anaerobic treatment (biogas plant) and an organic wastewater treatment plant. Moreover the digester will be dried in an additional plant. Identification of a carrier to ensure the run of the facility after the project run-time;
- Implementation of the identified pre-measures of wastewater and waste prevention and recycling;

- Water and land-use strategies (re-use of sludge in agriculture);

- Eco-balance and investigations of possibilities for a sustainable financing (coordinated with NGOs);

- Formulation of guidelines;

- Further training of representatives of the environmental institutions, consultants and authorities of the village (capacity building).



Figure 2. Flowchart of the pilot plant for treatment of wastewater, solid waste, and manure to be established in Dai Lam village

\section{Working programme}

\section{Phase 1: Investigations on basic information and man-} agement of a concept

The project started with a preliminary phase (three months) to carry out the necessary prearrangement in Hanoi and Germany. During this period a kick-off workshop with all stakeholders took place in Bac Ninh. Basic data was collected in the first year related to infrastructure, production and related processes, soil investigations with focus on old landfills and waters in the catchment area. Subsequently, a mass flow management concept and the concept for the treatment and processing technique will be developed under consideration of the real demands and the local boundary conditions.

\section{Phase 2: Implementation and scientific monitoring}

The partners VIS and HUT (see chapter 5 for details) are responsible for the planning, execution and installation of a suitable technology. In addition to the scientific monitoring of the plant operation, the operating company and the personnel will benefit of specialized training which assures a constrained working progress. Furthermore, more stakeholders (e. g. from the Department of Natural Resources and Environment) and staff of the Vietnamese project partners are regularly updated on the overall project progress and trained. 
After achieving an efficient operation management of the system, an international workshop with participation of German companies and experts will be organised in order to display the existing problems and suitable solutions of Vietnamese craft villages (capacity building). Possible former landfills and their impact on protected commodities will be investigated and assessed in one of the working packages of the project (groundwater monitoring).

All working steps are well documented in guidelines, which enables the operating company and other stakeholders to transfer the procedures to other craft villages. Based on these guidelines, the project consortium will provide the representatives of the environmental agencies and other responsible authorities with the documents for the operation of the facilities and complementary training material. The capacity building measures comprise the operation of the facility, integrated product management, environmentally sound production, sewage and residue treatment and work protection.

\section{Project partners}

\subsection{Partners in Germany}

- Technische Universität Dresden, Institute of Waste management and Contaminated Site Treatment, Prof. Dr. Peter Werner;

- Leibniz Universität Hannover, Institute of Water Quality and Waste Management, Dr. Dirk Weichgrebe;

- VIS Ltd., Berlin, Dr. Holger Appel;

- Herbst Umwelttechnik Ltd., Berlin, Dr. Leonhard Fechter.

\subsection{Partners in Vietnam}

- People's Committee Bac Ninh, DONRE Bac Ninh;

- Vietnam Academy of Science and Technology.

\section{Acknowledgements}

The authors would like to acknowledge the German Federal Ministry of Education and Research for supporting the research on water management in Vietnam. 